\title{
Interleukin-13 Receptor Subunit Alpha-1
}

National Cancer Institute

\section{Source}

National Cancer Institute. Interleukin-13 Receptor Subunit Alpha-1. NCI Thesaurus. Code C41230.

Interleukin-13 receptor subunit alpha-1 (427 aa, $49 \mathrm{kDa}$ ) is encoded by the human IL13RA1 gene. This protein is involved in cytokine-mediated signal transduction. 